\title{
Using Start Codon Targeted (SCoT) polymorphism for Genetic Diversity Analysis of three Red Sea fishes (Family: Carangidae)
}

\author{
Zeinab A. Mar'ie ${ }^{1}$ and Mohammad Allam ${ }^{2}$ \\ ${ }^{I}$ Biology Department, Faculty of Education, Hurghada, South Valley University, Egypt. \\ ${ }^{2}$ Zoology Department, Faculty of Science, South Valley University, Egypt.
}

\begin{abstract}
The taxonomical analysis of two genera Caranx and Carangoides is argumentative because of there are many similarities between them. In this work Start Codon Targeted (SCoT) polymorphism were used for studying the genetic diversity and relationships among three species of carangids, (Carangoides bajad, Caranx sexfasciatus and Caranx melampygus) collecting from Hurghada Red Sea, Egypt. The results revealed that there are of 325 fragments were generated by the Twelve primers in the three species. A total of 192 fragments were generated by the Twelve primers in the two species Carangoides bajad and Caranx sexfasciatus, out of these fragments 98 (51\%) were common between the two species, while 248 fragments were generated by the Twelve primers in the two species Carangoides bajad and Caranx melampygus, out of them 162 (65\%) were common between the two species, but it is striking that there are 210 fragments were generated by the Twelve primers and only 98 (47\%) fragments of them were common between the two species Caranx sexfasciatus and Caranx melampygus.
\end{abstract}

Keywords: Genetics, SCoT, Analysis, Fishes and Carangidae.

\section{Introduction}

Carangid fishes, can be known as jacks, trevallies, scads, or amberjacks are widely distributed in all tropical and subtropical seas. They are among the most economically important coastal pelagic fishes of the world, the family Carangidae contains approximately 140 species in about 30 genera (Laroche et al., 1984, Bannikov, 1987 and Lin and Shao, 1999). According to (Randall, 1982), some of carangids species entering the Red Sea reef environment. In this report we analysis three species of those fishes which entering to the Red Sea of Egypt (Carangoides bajad, Caranx sexfasciatus and Caranx melampygus) by using Start Codon Targeted technique (SCoT) perhaps for the first time in animals specially fishes.

Deoxyribonucleic acid (DNA) molecule is the basic material necessary for molecular genetics studies hence it contains all genetic information that directs the biological processes and functions of the life. Molecular genetics is the study of the structure and function of genes, but at the molecular level, in other words it is a field of science that combines genetics and molecular biology (Fulton, 2008). Polymerase chain reaction (PCR) has developed rapidly over the last decade and has become a popular technique for many genetic researches based on amplification DNA. This widespread of PCR is because of its simplicity, apparent and high ratio of success (Kumar and Gurusubramanian, 2011). Many DNA techniques have been useful for the arrival of genetic diversity in fishes (Park and Moran, 1994; O'Reilly and Wright, 1995; Carvalho and Hauser, 1998), but the implementation of genetic analysis based on DNA- marker in fishes research and stock development and management is still not fully maximized (Kocher et al., 1998 and Rashed et al., 2008 and 2009).

Start Codon Targeted (SCoT) are reproducible and dominant markers use a single 18-mer primer in the polymerase chain reaction and are based on the short conserved region in plant genes surrounding the ATG translation start (or initiation) codon and (Collard and Mackill, 2009). Start Codon Targeted technique (SCoT) has been successfully used in a wide range of plants species including rice, sugarcane, tritordeums, grape, peanut, potato, myrica, mango, rubra, garbanzo and Zea mays and this proved that, (SCoT) is useful method in assessment the genetic diversity, structure, cultivars and DNA fingerprinting of different species (Collard and Mackill, 2009; Luo et al., 2010; Gorji et al., 2011; Xiong et al., 2011; Amirmoradi et al., 2012; Gorji et al., 2012; Guo et al., 2012; Cabo et al., 2014; Fang-Yong and Ji-Hong, 2014, Que et al., 2014 and Vivodík et al., 2016). But through our finding of information, there no research about Start Codon Targeted (SCoT) polymorphisms in fishes specially in Egypt at least, since (SCoT) is mainly applied on plant tissues. So we wanted to estimate the effectiveness of (SCoT) on fish's tissues. The molecular structure of fish species is beneficial for quite identification of stocks, stock enhancement breeding programs, management for sustainable yield and preservation of genetic variation (Dinesh et al., 1993 and Tassanakajon et al., 1998).

Xiong et al., 2011 established that, the SCoT markers are expected to be linked to functional genes and corresponding traits, thus the amplicons can be converted to gene targeted marker system. Shortly, the SCoT polymorphism method is similar to RAPD and ISSR, because of the use of a single forward and reverse primer (Bhattacharyya et al., 2013). There are several advantages of SCoT technique, including low cost, simple operation, simple primer design, highly effective polymorphism, good reproducibility and good universality (Hu et al., 2009). 
This study reports on the use of Start Codon Targeted (SCoT) markers to investigate the relationships and genome specificity among three species (Carangoides bajad, Caranx sexfasciatus and Caranx melampygus) of family Carangidae of the Red Sea coral reef fishes in Egypt for the first time.

\section{Collection of samples}

\section{Materials And Methods}

The samples (Carangoides bajad, Caranx sexfasciatus and Caranx melampygus) were collected from Hurghada, Red Sea, Egypt. The samples were classified with the help of keys provided and descriptions of (Randall, 1982). The muscles tissues were immediately separated after capture and stored at $-20^{\circ} \mathrm{C}$ until DNA extraction.

\section{Extraction of genomic DNA:}

DNA was extracted from tissues of three carangid Red Sea fishes by DNeasy Tissue Mini Kit (Qiagen). DNA concentration was determined by diluting the DNA 1:5 in dH2O. The DNA samples were electrophoresed in $1 \%$ agarose gel against $10 \mu \mathrm{g}$ of a DNA size marker (Lambda DNA).

\section{SCoT Reaction and Thermocycling Profile:}

Twelve SCoT primers were used in this study (Table 1). PCR was performed in 25 ul reaction volume containing 1X PCR buffer, $1.75 \mathrm{mM} \mathrm{MgCl} 2,5 \mathrm{mM}$ of each dNTPs, $40 \mathrm{pM}$ oligonucleotide primer, $25 \mathrm{ng}$ genomic DNA and 1 Unit of Taq DNA polymerase. An initial denaturation step is used for 5 min at $94^{\circ} \mathrm{C}$ followed by 40 cycles at $94^{\circ} \mathrm{C}$ for 40 second, $50^{\circ} \mathrm{C}$ for 45 second and $72^{\circ} \mathrm{C}$ for $1 \mathrm{~min}$ and an extension cycle at $72^{\circ} \mathrm{C}$ for $7 \mathrm{~min}$. The amplification products were resolved by electrophoresis on $1.5 \%$ agarose gel containing ethidium bromide $(0.5 \mu \mathrm{g} / \mathrm{ml})$ in $1 \mathrm{X}$ TBE buffer. A $100 \mathrm{bp}$ DNA ladder was used as a molecular size standard. PCR products were visualized on UV light and photographed using a Gel Documentation System (BIO -RAD).

Table (1) illustrate the sequence of the twelve primers

\begin{tabular}{|l|l|}
\hline \multicolumn{1}{|c|}{ Primer } & \multicolumn{1}{c|}{ Sequence } \\
\hline Primer -1 & ACGACATGGCGACCACGC \\
\hline Primer -2 & ACCATGGCTACCACCGGC \\
\hline Primer -3 & ACGACATGGCGACCCACA \\
\hline Primer -4 & ACCATGGCTACCACCGCA \\
\hline Primer -5 & CAATGGCTACCACTAGCG \\
\hline Primer -6 & CAATGGCTACCACTACAG \\
\hline Primer -7 & ACAATGGCTACCACTGAC \\
\hline Primer -9 & ACAATGGCTACCACTGCC \\
\hline Primer -10 & ACAATGGCTACCACCAGC \\
\hline Primer -11 & ACAATGGCTACCACTACC \\
\hline Primer -20 & CAACAATGGCTACCACGC \\
\hline Primer -24 & CCATGGCTACCACCGCAG \\
\hline
\end{tabular}

\section{Data analysis}

The banding patterns generated by SCOT-PCR marker analysis compared to determine the genetic variation of the samples under study. Distinct amplification products scored as ' 1 ' for presence and ' 0 ' for absence of bands. The genetic similarity (Jaccard) was obtained by clustering according to the Unweighted PairGroup Method using Gene Tools-gel analysis software of SPSS (ver. 18).

\section{Results And Discussion}

According to Nelson 2006, The Carangidae fishes includes species with ecologically and economically important and consider one of the most morphologically various family in order Perciformes. Actually, some groups of this family have unclear taxonomic relationships, and changes the nomenclature of this group are typical (Laroche et al., 1984; Gunn, 1990 and Honebrink, 2000). Study the taxonomic analysis of the Caranx genus demonstrated that, some species with a wide geographic distribution and cryptic taxonomic features constitute species complex (Smith- Vanize and Carpenter, 2007).

It is striking that there are morphological similarities between Carangoides bajad from one side and Caranx sexfasciatus and Caranx melampygus, from the other side, so this study was carried to evaluate the potential of Start codon targeted polymorphism (SCoT) for revealing the genetic diversity and estimating the genetic similarity between the three species using Twelve SCoT primers (Table 1).

All primers reacted successfully with the genomic DNA of the studied fishes generated DNA fragments ranged in size from $160 \mathrm{bp}$. by primer (1) to $1900 \mathrm{bp}$. by primers (2 and 3). The number of amplified fragments varied from 16 by primer (5) to 36 by primer (3). 
Start codon targeted polymorphism (SCoT) technique was used to examine the genomic DNA of Carangoides bajad and produced 115 DNA fragments ranged in size approximately from $160 \mathrm{bp}$. by the primer (1) to $1900 \mathrm{bp}$. by the primer (3). The generated bands ranged in number from 6 bands by the primer (5) to 13 bands by the primer (3). The SCoT analysis using Twelve primers showed the number of bands in the Caranx sexfasciatus species was 77 bands. The large number of bands 9 generated by the primer (3), while the small number of bands 2 generated by the primer (6). The size of bands ranged from $180 \mathrm{bp}$ by the primer (7) to 1250 bp. by the primer (10). All the Twelve SCoT primers produced 133 band in the species of Caranx melampygus. The number of band amplified per primer varied from 7 by the primer (5) to 14 by the primer (3) and have size ranged from $210 \mathrm{bp}$. by the primer (20) to $1900 \mathrm{bp}$. by the primer (2).

Although several amplified fragments were shared in these three species, clearly distinguishable bands were evident from high number of polymorphic marker and appearance of unique bands between the three species (Carangoides bajad, Caranx sexfasciatus and Caranx melampygus). There are of 325 fragments were generated by the Twelve primers in the three species.

A total of 192 fragments were generated by the Twelve primers in the two species Carangoides bajad and Caranx sexfasciatus, out of these fragments $98(51 \%)$ were common and $94(49 \%)$ bands were polymorphic between the two species (Table 2), while 248 fragments were generated by the Twelve primers in the two species Carangoides bajad and Caranx melampygus, out of these fragments $162(65 \%)$ were common and 86 $(65 \%)$ bands were polymorphic between the two species (Table 3), but it is striking that there are 210 fragments were generated by the Twelve primers in the two species Caranx sexfasciatus and Caranx melampygus, out of these fragments $98(47 \%)$ were common and $112(53 \%)$ bands were polymorphic between the two species (Table 4).

Table (2): Number of amplified, Common and polymorphic DNA - fragments using Twelve SCoT primers in Carangoides bajad and Caranx sexfasciatus

\begin{tabular}{|c|c|c|c|c|c|c|c|}
\hline \multirow[t]{2}{*}{ No. } & \multirow{2}{*}{$\begin{array}{l}\text { Primer } \\
\text { code }\end{array}$} & \multirow{2}{*}{$\begin{array}{c}\text { Total of } \\
\text { amplified bands }\end{array}$} & \multicolumn{2}{|c|}{ Amplified bands } & \multirow{2}{*}{$\begin{array}{l}\text { Common } \\
\text { bands }\end{array}$} & \multirow{2}{*}{$\begin{array}{l}\text { Polymorphic } \\
\text { bands }\end{array}$} & \multirow{2}{*}{$\begin{array}{c}\text { Polymorphism } \\
\%\end{array}$} \\
\hline & & & $\begin{array}{c}\text { Carangoides } \\
\text { bajad }\end{array}$ & $\begin{array}{c}\text { Caranx } \\
\text { sexfasciatus }\end{array}$ & & & \\
\hline 1 & Primer - 1 & 18 & 12 & 6 & 6 & 12 & 66.7 \\
\hline 2 & Primer - 2 & 18 & 11 & 7 & 10 & 8 & 44.4 \\
\hline 3 & Primer - 3 & 22 & 13 & 9 & 10 & 12 & 54.5 \\
\hline 4 & Primer - 4 & 19 & 11 & 8 & 12 & 7 & 36.9 \\
\hline 5 & Primer - 5 & 9 & 6 & 3 & 6 & 3 & 33.3 \\
\hline 6 & Primer - 6 & 11 & 9 & 2 & 2 & 9 & 81.1 \\
\hline 7 & Primer - 7 & 16 & 9 & 7 & 8 & 8 & $\mathbf{5 0}$ \\
\hline 8 & Primer - 9 & 15 & 7 & 8 & 8 & 7 & 46.7 \\
\hline 9 & Primer - 10 & 16 & 9 & 7 & 8 & 8 & 50 \\
\hline 10 & Primer - 11 & 13 & 8 & 5 & 8 & 5 & 38.5 \\
\hline 11 & Primer - 20 & 16 & 9 & 7 & 6 & 10 & 62.5 \\
\hline 12 & Primer - 24 & 19 & 11 & 8 & 14 & 5 & 26.3 \\
\hline Total & & 192 & 115 & 77 & 98 & 94 & $49 \%$ \\
\hline
\end{tabular}

Table (3): Number of amplified, Common and polymorphic DNA - fragments using Twelve SCoT primers in Carangoides bajad and Caranx melampygus

\begin{tabular}{|c|c|c|c|c|c|c|c|}
\hline \multirow[t]{2}{*}{ No. } & \multirow{2}{*}{$\begin{array}{l}\text { Primer } \\
\text { code }\end{array}$} & \multirow{2}{*}{$\begin{array}{c}\text { Total of } \\
\text { amplified } \\
\text { bands }\end{array}$} & \multicolumn{2}{|c|}{ Amplified bands } & \multirow{2}{*}{$\begin{array}{l}\text { Common } \\
\text { bands }\end{array}$} & \multirow{2}{*}{$\begin{array}{c}\text { Polymorphic } \\
\text { bands }\end{array}$} & \multirow{2}{*}{$\begin{array}{c}\text { Polymorphism } \\
\%\end{array}$} \\
\hline & & & $\begin{array}{c}\text { Carangoides } \\
\text { bajad }\end{array}$ & $\begin{array}{c}\text { Caranx } \\
\text { melampygus }\end{array}$ & & & \\
\hline 1 & Primer - 1 & 24 & 12 & 12 & 12 & 12 & $\mathbf{5 0}$ \\
\hline 2 & Primer - 2 & 24 & 11 & 13 & 16 & 8 & 33.3 \\
\hline 3 & Primer - 3 & 27 & 13 & 14 & 14 & 13 & 48.1 \\
\hline 4 & Primer - 4 & 22 & 11 & 11 & 14 & 8 & 36.4 \\
\hline 5 & Primer - 5 & 13 & 6 & 7 & 8 & 5 & 38.5 \\
\hline 6 & Primer - 6 & 22 & 9 & 13 & 14 & 8 & 36.4 \\
\hline 7 & Primer - 7 & 22 & 9 & 13 & 16 & 6 & 27.3 \\
\hline 8 & Primer - 9 & 15 & 7 & 8 & 10 & 5 & 33.3 \\
\hline 9 & Primer - 10 & 20 & 9 & 11 & 14 & 6 & 30 \\
\hline 10 & Primer - 11 & 18 & 8 & 10 & 12 & 6 & 33.3 \\
\hline 11 & Primer - 20 & 20 & 9 & 11 & 16 & 4 & 20 \\
\hline 12 & Primer - 24 & 21 & 11 & 10 & 16 & 5 & 23.8 \\
\hline Total & & 248 & 115 & 133 & 162 & 86 & $35 \%$ \\
\hline
\end{tabular}


Using Start Codon Targeted (SCoT) polymorphism for Genetic Diversity Analysis of three Red Sea ..

Table (4): Number of amplified, Common and polymorphic DNA - fragments using Twelve SCoT primers in Caranx sexfasciatus and Caranx melampygus

\begin{tabular}{|c|c|c|c|c|c|c|c|}
\hline \multirow[t]{2}{*}{ No. } & \multirow{2}{*}{$\begin{array}{l}\text { Primer } \\
\text { code }\end{array}$} & \multirow{2}{*}{$\begin{array}{c}\text { Total of } \\
\text { amplified bands }\end{array}$} & \multicolumn{2}{|c|}{ Amplified bands } & \multirow{2}{*}{$\begin{array}{l}\text { Common } \\
\text { bands }\end{array}$} & \multirow{2}{*}{$\begin{array}{l}\text { Polymorphic } \\
\text { bands }\end{array}$} & \multirow{2}{*}{$\begin{array}{c}\text { Polymorphism } \\
\%\end{array}$} \\
\hline & & & $\begin{array}{c}\text { Caranx } \\
\text { sexfasciatus }\end{array}$ & $\begin{array}{c}\text { Caranx } \\
\text { melampygus }\end{array}$ & & & \\
\hline $\mathbf{1}$ & Primer - 1 & 18 & 6 & 12 & 6 & 12 & 66.7 \\
\hline 2 & Primer - 2 & 20 & 7 & 13 & 10 & 10 & $\mathbf{5 0}$ \\
\hline 3 & Primer - 3 & 23 & 9 & 14 & 14 & 9 & 39.1 \\
\hline 4 & Primer - 4 & 19 & 8 & 11 & 8 & 11 & 57.9 \\
\hline 5 & Primer - 5 & 10 & 3 & 7 & 2 & 8 & 80 \\
\hline 6 & Primer - 6 & 15 & 2 & 13 & 2 & 13 & 86.7 \\
\hline 7 & Primer - 7 & 20 & 7 & 13 & 12 & 8 & 40 \\
\hline 8 & Primer - 9 & 16 & 8 & 8 & 8 & 8 & $\mathbf{5 0}$ \\
\hline 9 & Primer - 10 & 18 & 7 & 11 & 10 & 8 & 44.4 \\
\hline 10 & Primer - 11 & 15 & 5 & 10 & 6 & 9 & 60 \\
\hline 11 & Primer - 20 & 18 & 7 & 11 & 8 & 10 & 55.6 \\
\hline 12 & Primer - 24 & 18 & 8 & 10 & 12 & 6 & 33.3 \\
\hline Total & & 210 & 77 & 133 & 98 & 112 & $53 \%$ \\
\hline
\end{tabular}

Figure 1: Marker profiles for three Red Sea fishes generated by SCoT primers; 1, 2, 3 and 4.

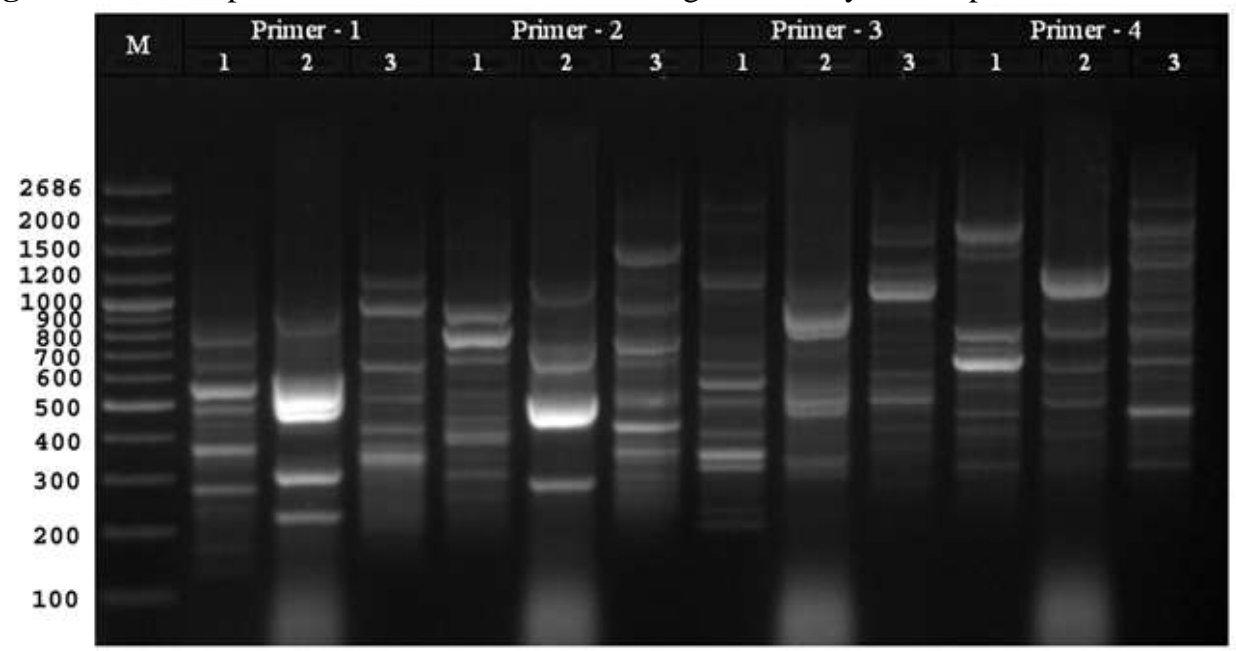

1- Carangoides bajad, 2- Caranx sexfasciatus, 3- Caranx melampygus and M Marker.

Figure 2: Marker profile for three Red Sea fishes generated by SCoT primers; 5, 6, 7 and 9.

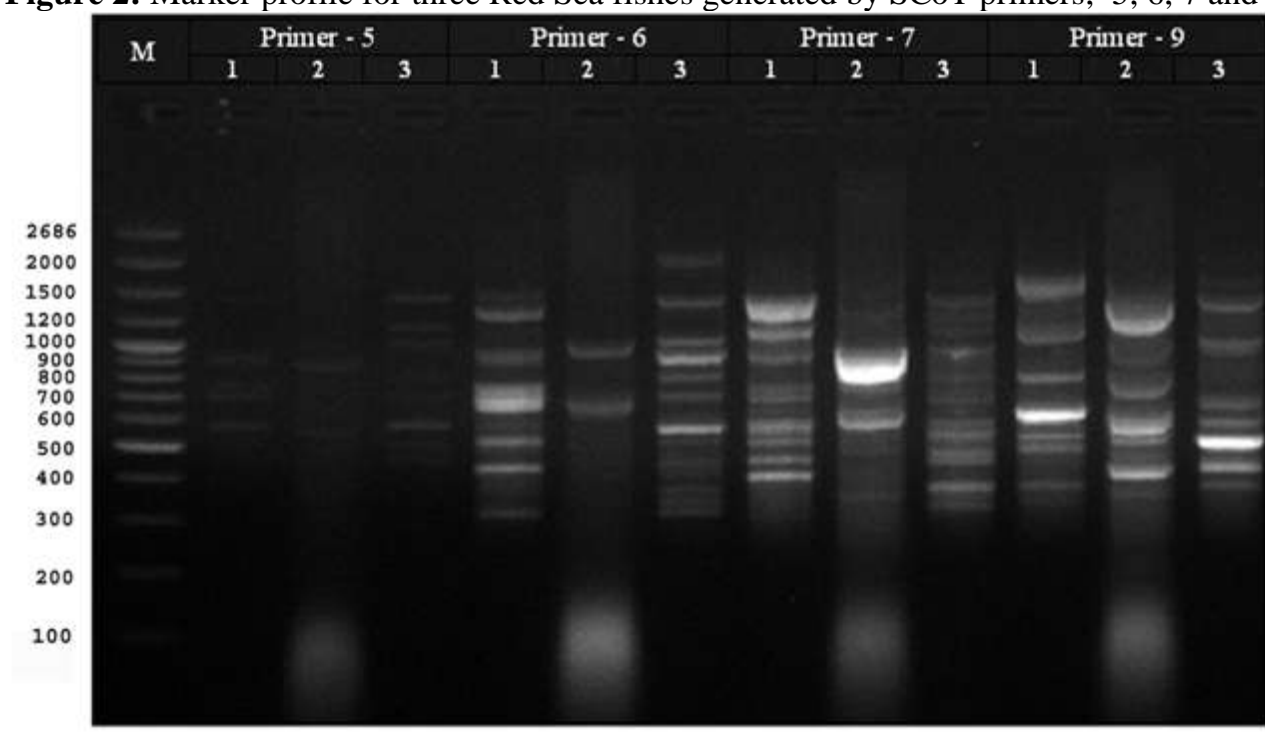


Figure 3: Marker profiles for three Red Sea fishes generated by SCoT primers; 10, 11, 20 and 24.
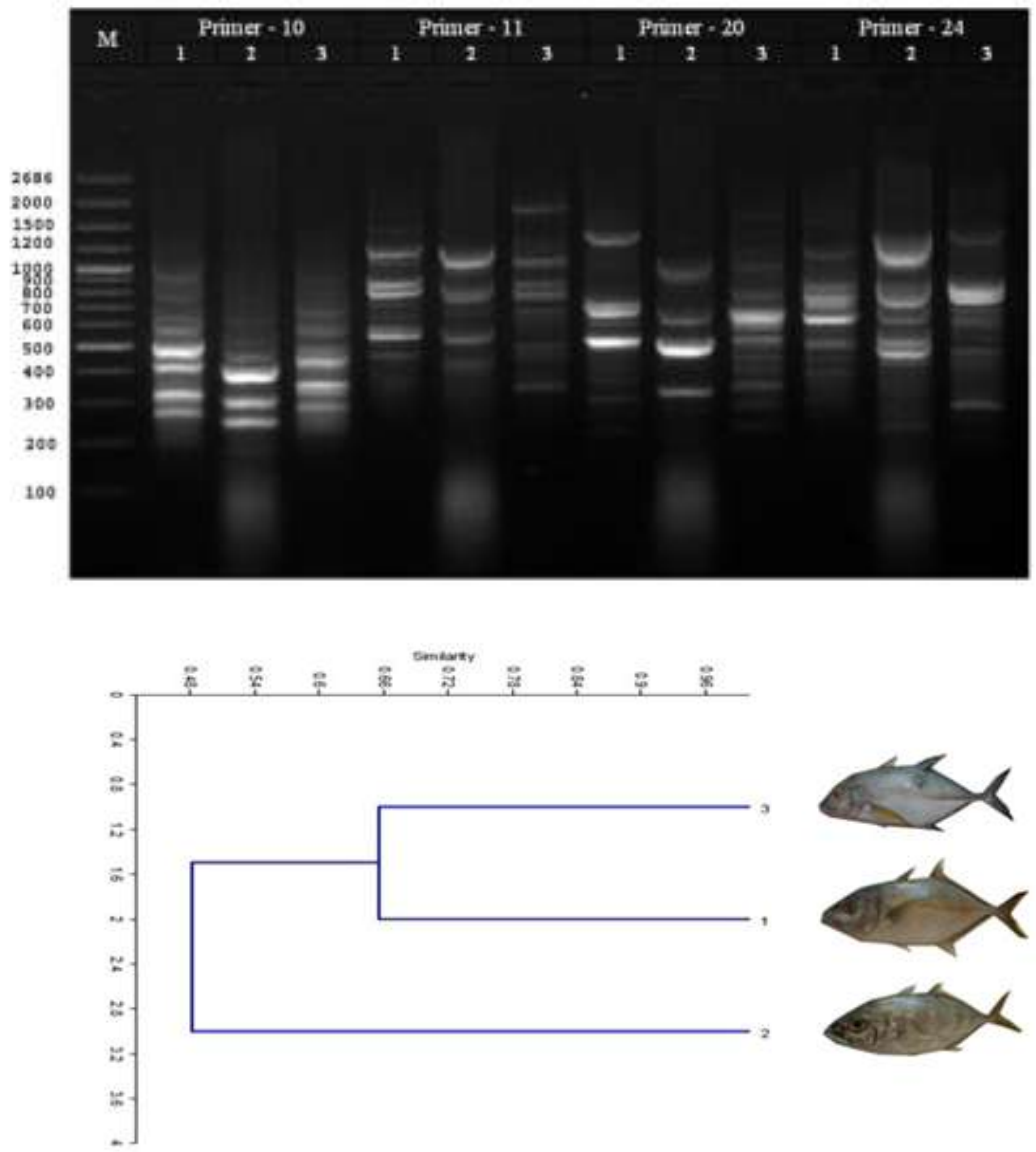

Fig.(4): Dendrogram demonstrating the relationship among Carangoides bajad, Caranx sexfasciatus and Caranx melampygus, based on data recorded from polylmorphism of SCoT markers, where1 Carangoides bajad, 2- Caranx sexfasciatus and 3-Caranx melampygus.

Dendrogram consisted of two cluster; (A) contained Caranx sexfasciatus, and (B) contained Carangoides bajad and Caranx melampygus.

Table (5) The Similarity matrix UPGMA Jaccard's Coefficient:

\begin{tabular}{|c|c|c|c|}
\hline \multicolumn{5}{|c|}{ Similarity Matrix } \\
\hline & Carangoides bajad & Caranx sexfasciatus & Caranx melampygus \\
\hline Carangoides bajad & $\mathbf{1 0 0}$ & & \\
\hline Caranx sexfasciatus & $\mathbf{5 1}$ & $\mathbf{1 0 0}$ & $\mathbf{1 0 0}$ \\
\hline Caranx melampygus & $\mathbf{6 5}$ & $\mathbf{4 7}$ & \\
\hline
\end{tabular}

Data of the presence / absence of DNA fragments of Carangoides bajad, Caranx sexfasciatus and Caranx melampygus were used to calculate the genetic similarity. Then based on the calculated genetic similarity presented in table (5) and Dendrogram as figure (4), an estimation of the relationship between the above species was concluded where the lowest genetic similarity 47 was observed between Caranx sexfasciatus and Caranx melampygus also these two species belong to the same genus Caranx, while the highest value $\mathbf{6 5}$ found between Carangoides bajad and Caranx melampygus.

Present study indicated that the least genetic distance was observed in Carangoides Bajad and Caranx melampygus these two species fell into a distinct cluster from other species Caranx sexfasciatus. This points out that the genus Carangoides is genetically closer and show similarity with the genus Caranx which gave the possibility to combine all these species into one genus, these is in agreement with (Smith-Vaniz, 1984 and Reed et al., 2002) who indicated that, Caranx show several morphological similarities that make it difficult to distinguish from other carangoides members, such similarities led various authors to classify these species into the same genus, and also with (Jacobina et al., 2014) who summarized that, genus Caranx is taxonomically dialectical due to it has little morphological diversity among species, and because of its relationship with genus Carangoides. 
This method of DNA fingerprinting is important, since it is relatively easy to obtain valuable data, the above result of SCoT markers may be recommended as quick and reliable discrimination technique compared with other marker approaches, for detecting genetic relationship among Carangoides bajad, Caranx sexfasciatus and Caranx melampygus. So the results demonstrate that Start Codon Targeted (SCoT) technology represents a useful and reliable tool for species discrimination and for detecting genetic relationships in these species, and. The results are relevant for their conservation as well as aid in the understanding of the phylogeny and biogeography of these Red Sea fishes.

\section{Conclusion}

The present study was showed the usefulness of Start codon targeted polymorphism (SCoT) for studying the genetic diversity in animal tissues specially fishes and revealed the genetic similarity between genus Carangoides and genus Caranx, which allows likelihood to classify these species into the same genus.

\section{Acknowledgement}

The authors are very grateful to Prof. Dr. Abdel-Basset M. Ebied; professor of cytogenetics, Biological Science, Faculty of Science, Taif University, KSA, for his continuous advice and ever-ready help in any time.

\section{References}

[1]. Amirmoradi, B.; Talebi, R. and Karami, E. (2012): Comparison of genetic variation and differentiation among annual Cicer species using start codon targeted (SCoT) polymorphism, DAMD-PCR, and ISSRR markers. Plant Syst. Evol., 298(9): 1679-1688.

[2]. Bhattacharyya, P.; Kumaria, S.; Kumar, S. and Tardon, P. (2013): Start Codon Targeted (SCoT) marker reveals genetic diversity of Dendrobium nobil Lindl., an endangered medicinal orchid species. Gene, 529(1): 21-26.

[3]. Bannikov, A. F. (1987): On the taxonomy, composition and origin of the Family Carangidae. J. Ichthyol., 27(1): 1-8.

[4]. Cabo, S.; Ferreira, L.; Carvalho, A.; Martins-lopes, P.; Martin, A.; Lima-Brito, J. E. (2014): Potential of Start Codon Targeted (SCOT) markers for DNA fingerprinting of newly synthesized tritordeums and their respective parents. J. Appl. Genet., 55(3): 307-312.

[5]. Carvalho, G. R.; Hauser, L. (1998): Advances in the molecular analysis of fish population structure. Ital. J. Zool., 65: 21-33.

[6]. Collard, B. C. Y. and Mackill, D. J. (2009): Start Codon Targeted (SCOT) Polymorphism: a simple novel DNA marker technique for generating gene-targeted markers in plants. Plant Mol. Biol. Rep., 27: 86-93.

[7]. Dinesh, K. R.; Lim, T. M.; Chua, K. L.; Chan, W. K. and Phang, V. P. (1993): RAPD analysis an efficient method of DNA fingerprinting in fishes. Zoolog Sci., 10(5): 849-854.

[8]. Fang-Yonga, Ch. and Ji-Honga, L. (2014): Germplasm genetc diversity of Myrica rubra in Zhejiang Province studied using interprimer binding site and start codon-targeted polymorphism markers. Sci. Hortc., 170: 169-175.

[9]. Fulton, J. E. (2008): Molecular genetics in a modern poultry breeding organization. World's Poultry Science Journal, 64(2): 171176.

[10]. Gorji, A. M.; Matyas, K. K.;Dublecz, Z.; Decsi, K.; Cernak, I.; Hoffmann, B.; Taller, J. and Polgar, Z. (2012): In vitro osmotic stress tolerance in potato and identification of major QTLs. Am. J. Pot. Res., 89: 453-464.

[11]. Gorji, A. M.; Poczai, P.; Polgar, Z.; Taller, J. (2011): Efficiency of arbitrarily amplified dominant markers (SCoT, ISSR and RAPD) for diagnostic fingerprinting in tetraploid potato. Am. J. Pot. Res., 88(3): 226-237.

[12]. Guo, D. L.; Zhang, J. Y. and Liu, C. H. (2012): Genetic diversity in some grape varieties revealed by SCoT analysis. Mol. Biol.Rep., 39(5): 5307-5313.

[13]. Gunn, J. S. (1990): Revision of selected genera of the family Carangidae. Rec. Austral. Mus., 12: 1-77.

[14]. Honebrink, R. R. (2000): A Review of the Family Carangidae, With Emphasis on Species Found in Hawaiian Waters. DAR Technical Report (Honalulu: Department of Land and Natural Resources). 20-01: 1-43.

[15]. Hu, C.; He, X. H.; Luo, C. Zhu, J. H. et al. (2009): The optimization of SCoT-PCR system of Longan (Dimocarpus longan). Genom. Appl. Biol. 28: 970-974.

[16]. Jacobina, U. P.; Bertollo, L. A.; Bello Cioffi, M. and Molina, W. F. (2014): Physical mapping of 18S and 5S genes in pelagic species of the genera Caranx and Carangoides (Carangidae). Genet. Mol. Res., 13(4): 9628-9635.

[17]. Kocher, T. D.; Lee, W. J.; Sobolewska, H.; Penman, D. and McAndrew, B. (1998): A genetic linkage map of a cichlid fish, the Tilapia (Oreochromis niloticus). Genetics, 148(3): 1225-1232.

[18]. Kumar, N. S. and Gurusubramanian, G. (2011): Random amplified polymorphic DNA (RAPD) markers and its applications. Sci. Vis. 11(3): 116-124

[19]. Laroche, W. A, Smith-Vaniz, W. F. and Richardson, S. L. (1984): Carangidae development. in HG Moser,WJ Richardson, eds. Ontogeny and systematic of fishes. Am. Soc. Ichthyol. Herpeto el., Spec. Publ. 1: 510-522.

[20]. Lin, P. L. and Shao, K. T. (1999): A review of the carangid fishes (Family Carangidae) from Taiwan with Description of Four New Records. Zoological studies 38(1):33-68.

[21]. Luo, C.; He, X. H.; Chen, H.; Ou, S. J.; Gao, M. P. (2010): Analysis of diversity and relationships among mango cultivars using Start Codon Targeted (SCoT) markers.Biochem. Syst. Ecol., 38(6): 1176-1184.

[22]. Nelson, J. S. (2006): Fishes of the World. John Wiley and Sons, New York.

[23]. O'Reilly, P. and Wright, J. M. (1995): The evolving technology of DNA fingerprinting and its application to fisheries and aquaculture. J. Fish Biol., 47(sA): 29-55.

[24]. Park, L. K. and Moran, P. (1994): Developments in molecular-genetic techniques in fisheries. Rev. Fish Biol., 4(3): 272-299.

[25]. Que, Y. X.; Pan, Y. B.; Lu,Y. H.; Yang, C.; Yang, Y. T.; Huang, N. and Xu, L.P. (2014): Genetic analysis of diversity within a Chinese local sugarcane germplasm based on start codon targeted polymorphism. Bio. Med. Res., Int.,468375.

[26]. Rashed, M. A., Saad, Y. M.; EL-Seoudy, A. A. and Ibrahim, M. M. (2009): Gene flow in some Oreochromis niloticus populations based on SSR linked markers to MHC loci class I. J. Boil. Chem. Environ. Sci., 4(1): 319-331.

[27]. Rashed, M. A.; Saad, Y. M.; Ibrahim, M. M. and EL-Seoudy, A. A. (2008): Genetic structure of Natural Egyptian Oreochromis niloticus evaluated from dominant DNA markers. Global Veterinaria, 2(2): 87-91. 
[28]. Randall, J. E. (1982): the diver guide to Red Sea reef fishes. Publishing limited 20 Berkeley Street, Berkeley square London Wix 5AE.

[29]. Reed, D. L.; Carrpenter, K. E. and deGravelle, M. J. (2002): Molecular systematic of the Jacks (Perciformes: Carangidae) based on mitochondrial cytochrome b sequences using parsimony, likelihood, and Bayesian approaches. Mol. Phylogenet. Evol. 23(3): 513-524.

[30]. Smith-Vaniz, W. F. (1984): Carangidae Relationships. In: Ontogeny and Systematics of Fishes (Moser HG, Richards WJ, Cohen DM, Fahay MP, et al, eds). Am. Soc. Ichthyol. Herpetol. 522-530.

[31]. Smith-Vaniz, W. F. and Carpenter, K. E. (2007): Review of the crevalle jacks, Caranx hippo complex (Teleostei: Carangdae), with a description of a new species from West Africa. Fish. Bull., 105: 207-233.

[32]. Tassanakajon, A.; Pongsomboon, S.; Jarayabhand, P.; Klinbunga, S. and Boonsaeng, V. V. (1998): Genetic structure in wild population of black tiger shrimp (Penaeus monodon) using randomly amplified polymorphic DNA analysis. J. Mar. Biotechnol., 6(4): 249-254

[33]. Vivodík, M.; Gálová, Z.; Balážová, Ž. and Petrovičová, L. (2016): Start codon targeted (scot) polymorphism reveals genetic diversity in european old maize (zea mays 1.) Genotypes. Potravinarstvo, 10(1): 563-569.

[34]. Xiong, F.; Zhong, R.; Han, Z.; Jiang, J.; He, L.; Zhuang, W. and Tang R. (2011): Start Codon Targeted polymorphism for evaluton of functional genetic variation and relationships in cultivated peanut (Arachs hypogaeal L.).Genotypes. Mol. Biol. Rep., 38(5): 3487-3494. 